Alexandra Palace tower at opposite ends of the main hall. The B.B.C. provided several technical exhibits, including a telovision studio and control room in operation. A sound-recording van, complete with studio and associated apparatus, a motor-car fitted up for film recording purposes, and the 80-ft. telescopic aerial of the mobile television unit were also part of the display provided by the B.B.C. The Post Office demonstrated apparatus used for short. wave radio telegraph and telephone purposes, and illustrated the various stages in the dispatch and receipt of telegrams. Other novel features included technical exhibits by the radio departments of the services, such as field equipment as used by the Royal Corps of Signals, a replica of the wireless office of a destroyer by the Royal Navy, and a layout of the various electrical and radio equipment of aircraft by the Royal Air Force. An interesting and popular feature on the stand of the latter service was a 'link trainer', designed to represent the cockpit of a modern aircraft. It contains all the controls and equipment of a real cockpit, and with it all conditions of flying can be simulated on the ground. The exhibit was used to demonstrate the manner in which a pilot may fly in fog or at night, navigating entirely. with the aid of wireless instruments receiving signals from beacons on the ground.

Reverting to the manufacture and production of ordinary broadcasting receivers, a number of firms had contributed to the model factory which was set up in the exhibition. Various stages in the assembly and production of receivers or their components were shown in full operation under normal factory conditions. In addition, the various stages in the assembly of several manufacturers' standard receivers were shown on a rotating drum model in continuous operation. This section of the exhibition was designed not only to interest the technical enthusiast but also as an attempt to induce the ordinary listener to learn something of the internal construction and mode of operation of his receiving set.

Altogether, the exhibition demonstrated a successful attempt on the part of the organizers to make a wider appeal to the broadcast listening public, and it was extremely unfortunate that it was held during a period of such acute international tension.

\section{R. L. S.-R.}

\title{
DENTITION OF AUSTRALOPITHECUS (PLESIANTHROPUS)
}

\begin{abstract}
A COMPARATIVE and phylogenetic study of A the dentition of the extinct South African man-ape Australopithecus (Plesianthropus) trans. vaalensis Broom has been made by W. $\mathrm{K}$. Gregory and Milo Hellman, who visited South Africa in 1938 at the invitation of Dr. Robert Broom and Prof. Raymond Dart to examine the evidence at first hand for this purpose (Annals of the Transvaal Inseum, 19, 4 ; 1939).

One of the most astounding features of the type A. transvaalensis is the combination of a natural braincast, which is somewhat smaller than that of a large gorilla, with a dentition of almost human appearance. According to the experience of palæon. tologists the material available, though insufficient to satisfy statistical requirements, is adequate for determining the systematic position of Plesianthropus among the higher primates; and it is affirmed with Broom that in South Africa there once lived apes which had almost become men.

In the female Plesianthropus the premaxillary prognathism is much more pronounced than in the Ramapithecus from the Siwalik Hills, though the latter is a much smaller and more delicately built form. As compared with Sinanthropus the premaxillomaxillary regions of Plesianthropus are more prognathous. Likewise in the lower jaw, the available evidence indicates that the forepart of the jaw in Paranthropus was shorter and more retracted than in the apes, and was approaching the stage of Sinanthropus. In this respect Paranthropus was structurally intermediate between the existing apes and primitive man. The excessive thickness of this jaw and the extreme flattening of the facial plate are unique characters, which though by no means excluding Paranthropus from the dryopithecine stock, are conspicuous differences from Sinanthropus
\end{abstract}

and other hominids, and tend to justify Dr. Broom's choice of the name Paranthropus as indicating a side branch of the pre-human stock.

Turning to the evidence of the teeth themselves, tho upper central incisor of Plesianthropus is un. known, but indications point to a derivation from certain conditions present in Siwalik dryopithecines, and from this stage the Sinanthropus-Mongoloid series (with extreme shovel-shaped first and second incisors) is derivable merely by further emphasis in the same direction. In modern man further emphasis of the method of growth produces peg-like crowns, while an emphasis on the basal swelling sometimes produces results observable in Palæanthropic man and some modern apes. Hence in respect to the stage of evolution of the upper permanent incisors Plesian. thropus was intermediate between the ancestral dryopithecine stock and the primitive palcanthropic man; and it was more primitive than most modern anthropoid apes.

In regard to the canines Plesianthropus, starting from a primitive dryopithecine stage, was again approaching human conditions in the form and relations of its upper and lower canines. The small size of the canine teeth favours the conclusion that the small size of the canines in modern man is due to a secondary reduction. The lower canines are closer to Sinanthropus than to Sivapithecus. The edge-to-edge bite of upper to lower canines is again a primitive hominid condition, though occurring occasionally in old, very much worn, ape teeth.

In all the features of the premolars Plesianthropus was again intermediate between the primitive dryopithecus and the early human stage. Its upper premolars are more primitive than those of Sinanthropus in having lower, less taurodont, crowns and divergent buccal and lingual roots. 
The molars, both upper and lower, in the South African fossil man-apes are unusually large, being exceeded only by Sivapithecus giganteus and by male gorillas. They differ, however, from those of gorilla, chimpanzee and other modern apes by certain easily recognizable peculiarities. In several respects their pattern has progressed towards the primitive human stage. It is not improbable that the great size of the third upper and lower molars was only a temporary phase preceding the reduction of these teeth in man.

The evidence from the Taungs infant is completely concordant with that of the Sterkfontein and Krom. draai adults, namely, that there lived in the upper Pleistocene of South Africa a group of small-brained man-apes that were derived from the widespread dryopithecine stock and were the less progressive cousins of man.

\section{EIGHTH INTERNATIONAL CONGRESS OF REFRIGERATION}

$\mathrm{P}$ LANS are being made to hold an international refrigeration congress at Cologne and Berlin during July 1-6, 1940. These congresses are held at intervals of about four years under the auspices of the International Institute of Refrigeration, which was set up by an international convention in 1920 and is supported by the majority of the nations.

After the Hague Congress in 1936, the scientific and technical side of the work of the International Institute of Refrigeration was reorganized and the control of that work entrusted to seven commissions, under a technical board composed of the presidents of the commissions dealing with various aspects of refrigeration. The reorganization became effective in 1938, when meetings of the commissions and technical board were convened in the rooms of the Royal Society. A one-day Conference on Refrigeration was also held following these meetings, and at this conference a number of papers were read which had been selected to embrace topics of especial interest to refrigerationistis.

On July 14-16 last, similar meetings were held at Baden Baden and Karlsruhe, Germany. At the meetings of the technical board, a draft programme for the 1940 Congress was outlined.
On July 15, a Conference on Refrigeration took place at the Technical University at Karlsruhe, which has a department dealing with the engineering and physical side of refrigeration. In the grounds of the University is situated the Reich Institute of Foodstuff Preservation which is under the Ministry of Agriculture.

At the Refrigeration Conference four papers were read. Georges Claude dealt with the production and utilization of krypton. $\mathrm{He}$ indicated the advantages of the use of krypton for filling incandescent lamps, and stated that the production must be a separate field of activity rather than a byproduct from liquid oxygen. G. Maiuri described machines working on the absorption principle and diffusing the refrigerant vapour in an inert gas. $\mathrm{He}$ stated that it is possible to attain temperatures below $-100^{\circ} \mathrm{C}$. Ezer Griffiths dealt with various forms of hygrometers adapted to meet special requirements, and with humidity control. R. Plank dealt with gir-conditioning in deep mines.

The meetings of the Technical Board were attended by representatives of various nationalities, and at the Refrigeration Conference there was a good attendance of German refrigerationists.

\section{THE CAUSATION OF APPENDICITIS}

A PPENDICITIS is an inflammation around the cacum, involving the vermiform appendage, and frequently associated with perforative ulceration. Previous to 1900 , the disease was generally described under the names 'typhlitis' and 'perityphlitis'. The modern term 'appendicitis' began to be used in America between 1890 and 1900, and as a cause of death it first appears in the Registrar-General's annual report for 1901 .

The immediate cause of appendicitis is a bacterial infection, but although the disease is a common one, the causes that predispose or precipitate an attack still remain but little understood, though stagnation of the intestinal contents in the appendix resulting in the formation of hard concretions is probably an important factor in many cases. There is a certain amount of information which suggests that habits of life, and in particular dietary habits, are of importance in predisposing to the disease.

In an endeavour to elucidate the causation of appendicitis, Dr. Natthew Young and Mr. W. T. Russell have surveyed the mortality statistics of Great Britain and of other countries and the statistics of certain hospitals, and their report is now published ("Appendicitis : A Statistical Study". Medical
Research Council, Special Rep. Series, No. 233. H.Mr. Stationery Office. 1s. net). The figures relating to the frequency of appendicitis confirm that it is very prevalent and that it has been on the increase in recent years. Another point brought out is that the mortality in the highest social class is at least two and a half times greater than in the poorest social class, although the majority of diseases, especially those involving bacterial action, are commoner among poorer people. A curious feature of the mortality rates from appendicitis in women is that the figures strongly indicate that the mortality is greater among single than among married women.

The suggestion has been made that the nature of the diet may have an influence in predisposing to appendicitis, either an excess of food or possibly certain types of food, and both of these factors are probably more common among the well-to-do. The taking of purgatives or laxatives is another cause suggested, and this practice is probably more common in the higher social class and among women. No data bearing on these factors were obtained, though it is significant that the mortality from appendicitis in females fell during the war years 1915-18, when food restrictions were imposed, and increased afterwards. 